\title{
PDGF Enhancement of IL-1 Receptor Levels in Smooth Muscle Cells Involves Induction of an Attachment-Regulated, Heparan Sulfate Binding Site (IL-1RIII)
}

\author{
Soraya Valles, Christopher J. Caunt, Michelle H. Walker, and Eva E. Qwarnstrom \\ Cell Biology Unit (SV, CJC, MHW, EEQ), Division of Genomic Medicine, University of Sheffield, Sheffield, United \\ Kingdom; and the Department of Pathology (EEQ), University of Washington, Seattle, Washington
}

\begin{abstract}
SUMMARY: This study shows that increase in IL-1 receptor levels by platelet derived growth factor (PDGF) involves an enhancement of a matrix-dependent, low-affinity receptor that constitutes a heparan sulfate. Fibronectin attachment caused pronounced alterations in IL-1 receptor function in smooth muscle cells, involving a pronounced increase in cell surface binding from an average of 2,000 up to approximately 8,000 receptors/cell and an increase in affinity $\left(K_{\mathrm{a}}\right)$ of the type I receptor from 1.8 $\pm 0.9 \times 10^{9}$ to $3.7 \pm 0.5 \times 10^{9} \mathrm{M}^{-1}$. PDGF stimulation similarly enhanced the level of cell surface binding by between $30 \%$ and $100 \%$, with, in general, less effect on cells plated on fibronectin. Further, PDGF had a pronounced effect on the type I receptor affinity in the absence of matrix attachment, increasing the $\mathrm{K}_{\mathrm{a}}$ from $1.77 \pm 0.93 \times 10^{9}$ to $5.1 \pm 2.1 \times 10^{9} \mathrm{M}^{-1}$. Scatchard analyses revealed that PDGF, similarly to fibronectin attachment, caused enhancement of a second low-affinity binding site. Antibody blocking showed that approximately $50 \%$ of the attachment-induced increase was independent of type I receptor binding. Further, a similar fraction of the cell surface interaction was blocked by soluble heparan sulfate and dependent on cell binding to the heparan binding site. Cross-linking demonstrated that, in addition to the type I receptor, IL-1 bound to a second high molecular weight complex of $300 \mathrm{kd}$, induced by fibronectin attachment as well as by PDGF in the absence of matrix. Biochemical analyses demonstrated that this second site constitutes a heparan sulfate, which directly interacted with the type I receptor after recruitment to the complex, and which bound up to $50 \%$ and $25 \%$ of the ligand after fibronectin attachment and PDGF stimulation, respectively. The data show that PDGF induces an attachment-regulated low-affinity IL-1 binding site in smooth muscle cells, constituting a heparan sulfate. Correlation of the recruitment of this component to the IL-1 receptor complex with structural regulation of receptor function and enhancement of IL-1-mediated responses suggests that this is a significant mechanism in PDGF augmentation of local inflammatory responses during vessel wall pathogenesis. (Lab Invest 2002, 82:855862).
\end{abstract}

$D$ evelopment of atherosclerosis has the hallmark of a response to injury, with a significant inflammatory component (Ross, 1993). During this process, smooth muscle cell (SMC) proliferation and migration are mainly regulated by platelet-derived growth factor (PDGF) secreted by activated macrophages (Bornfeldt et al, 1995; Heldin and Westermark, 1990; Raines and Ross, 1993). Further, IL-1, also a macrophage product, induces PDGF secretion from SMCs, thus activating proliferation via an autocrine loop (Dower et al, 1990; Raines et al, 1989). IL-1 also plays a direct role in the development of the disease by affecting the metabolism of extracellular matrix components

\section{DOI: 10.1097/01.LAB.0000020420.07575.3F}

Received January 14, 2002.

This work was supported by Grant Q0502 from the Arthritis and Rheumatism Council, and Grants PG 97112 and FS 99038 from the British Heart Foundation (to EEQ).

Address reprint requests to: Professor Eva E. Qwarnstrom, Cell Biology Unit, Division of Molecular and Genetic Medicine, Royal Hallamshire Hospital, University of Sheffield, Glossop Road, Sheffield, S1O 2JF, UK. E-mail: E.Qwarnstrom@Sheffield.ac.uk
(Wight, 1995). Many of the regulatory events are mediated through IL-1 induction of NF- $\kappa \mathrm{B}$, a pathway strongly activated in SMCs during development of atherosclerosis (Brand et al, 1996).

SMC biologic responses are dependent on the milieu, the surrounding cells, and components of the extracellular matrix. Effects are induced through cell matrix interactions, and through selective binding of plasma proteins, growth factors, cytokines, and enzymes by matrix components, regulating cell behavior during the formation of the atherosclerotic plaque (Wight, 1995; Wight et al, 1992). We have found that extracellular matrix attachment regulates IL-1-mediated signal transduction in SMCs. In particular, it enhances activation of the NF- $\kappa \mathrm{B}$ pathway, after rapid effects on cell attachment the cytoskeleton (Qwarnstrom et al, 1991, 1994).

Regulation of IL-1 receptor function is a potent mechanism for affecting inflammatory responses. Earlier studies have documented pronounced effects of PDGF on type I IL-1 receptor levels (Bonin and Singh, 1988). We have recently demonstrated that matrixinduced enhancement of inflammatory responses cor- 
relates with recruitment of an attachment-dependent IL-1 receptor complex component, constituting a heparan sulfate (Valles et al, 1999). This study investigates the role of PDGF in regulation of this novel IL-1 receptor component in SMCs.

The data show that PDGF induces an increase in $\mathrm{IL}-1$ receptor levels, both in the presence and absence of matrix. They also demonstrate that the PDGFinduced enhancement in IL-1 binding is due, in part, to a type I receptor-independent interaction with a matrix-regulated heparan sulfate component, after its recruitment to the IL-1 receptor complex.

\section{Results}

IL-1 binding studies demonstrated an attachmentinduced increase in receptor levels in SMCs (Fig. 1a). Thus, cells attached to fibronectin showed a higher

a

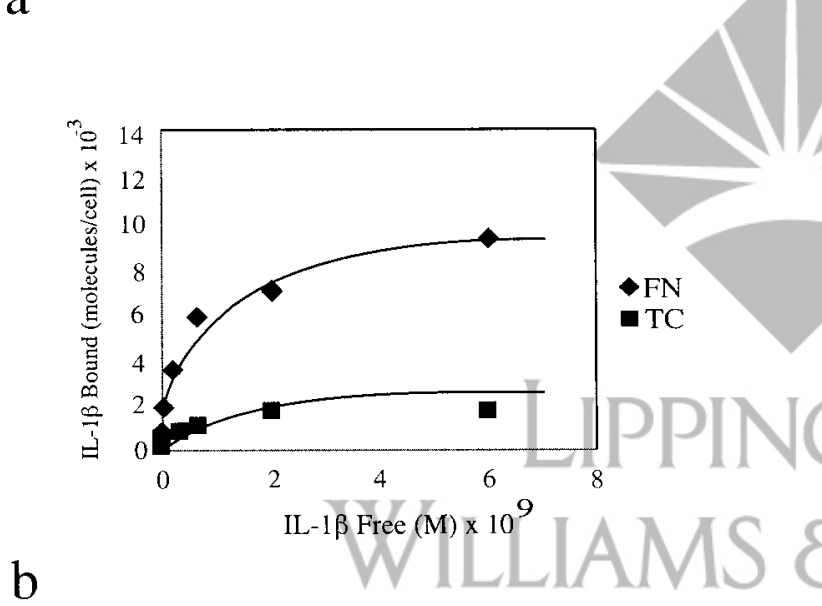

$\mathrm{b}$

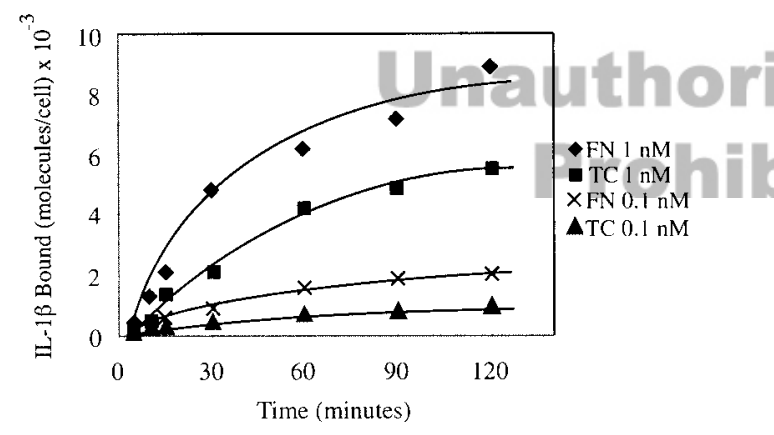

Figure 1.

Fibronectin attachment causes a pronounced increase in IL-1 receptor levels in smooth muscle cells. a, Cells plated on fibronectin (FM) or on bare tissue culture plates $(T C)$ were incubated in the cold $\left(4^{\circ} \mathrm{C}\right)$ for 2 hours with various concentrations of radiolabeled IL- $1 \alpha$, as indicated, and the level of specific receptor binding determined. Nonspecific binding, measured in the presence of 100 -fold excess unlabeled ligand has been subtracted from the data, and the continuous curves calculated from the best-fit parameter values. b, Cells plated on fibronectin (FM) or on bare tissue culture plastic $(T C)$, as in a, were incubated with various concentrations of radiolabeled IL- $1 \alpha$ ( 0.1 to $1 \mathrm{~nm}$ ) over time, as indicated, and the level of cell surface receptor binding determined, as in a. Data shown demonstrate binding for two concentrations and represent the mean of three experiments. level of cell surface binding $\left(8.9 \pm 0.82 \times 10^{3}\right.$ receptors/cell) than cells on bare tissue culture plastic $(2.8$ $\pm 0.54 \times 10^{3}$ receptors/cell); an average $3.0 \pm 0.17-$ fold increase. Analyses of binding kinetics at two concentrations of IL-1 (0.1 and $1 \mathrm{~nm}$ ) (Fig. 1b) further revealed an increase in association rate constant $\left(\mathrm{K}_{\mathrm{on}}\right)$ of the type I receptor in cells attached to fibronectin from $6.8 \times 10^{6}$ to $2.99 \pm 1.41 \times 10^{7} \mathrm{M}^{-1}$ minutes $^{-1}$.

The PDGF-induced effect was assessed by incubation with saturating levels of the growth factor and demonstrated an increase in IL-1 receptor binding, in both the presence and absence of fibronectin attachment, which was maximal between 12 and 24 hours of stimulation (Fig. 2). The separate and combined effects of matrix attachment and PDGF, from a representative experiment, are shown in Figure 3. On average, PDGF caused an increase from $1.3 \pm 0.1 \times 10^{3}$ to $2.2 \pm 0.1 \times 10^{3}$ receptors/cell in cells on tissue culture plates. Corresponding levels in cells on fibronectin were $6.4 \pm 0.2 \times 10^{3}$ and $8.4 \pm 1.3 \times 10^{3}$ receptors/cell in the absence and presence of PDGF, respectively (Fig. 3a). Fibronectin attachment caused an increase of up to 3- to 4-fold in receptor levels, whereas PDGF stimulation caused a $50 \%$ to $100 \%$ enhancement, with less effect in the presence of matrix attachment. The combination of the two agonists showed no more than additive effects. Further analysis by plotting in the Scatchard coordinate system revealed that the increase in receptor binding by both PDGF and fibronectin-attachment included induction of a second low-affinity binding site (Fig. 3b). Thus, whereas the data from cells plated on tissue culture plastic fitted a straight line, two sites based on affinities were demonstrated in the presence of fibronectin attachment or after stimulation with PDGF. 5 In addition, PDGF stimulation resulted in an increase in the type I IL-1 receptor affinity $\left(\mathrm{K}_{\mathrm{a}}\right)$ from 1.79 $\pm 0.92 \times 10^{9}$ to $3.17 \pm 1.35 \times 10^{9} \mathrm{M}^{-1}$, the same as that induced by fibronectin $\left(3.38 \pm 1.39 \times 10^{9} \mathrm{M}^{-1}\right)$ (Fig. 4a). In comparison, induction of the second

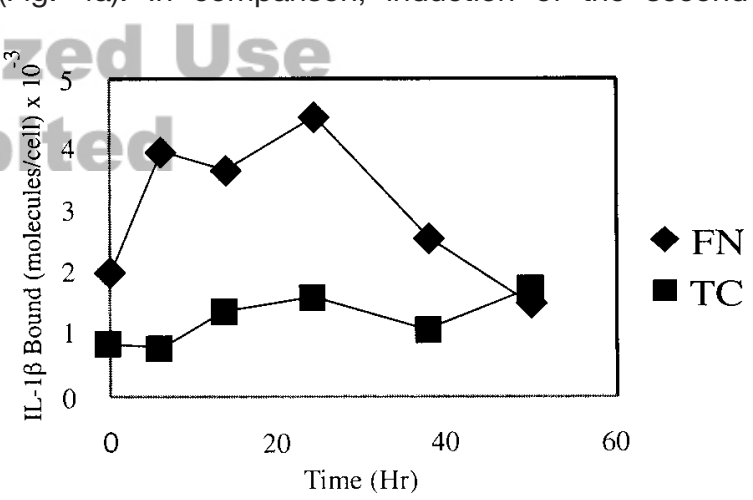

Figure 2.

Platelet derived growth factor (PDGF) induces enhancement in IL-1 receptor binding in smooth muscle cells in the presence and absence of matrix. Cells were plated in 24-well culture dishes $\left(2.5 \times 10^{4}\right.$ per well) on fibronectin $(F M)$ or on bare tissue culture plastic $(T C)$, as described previously and incubated with PDGF $(1 \mathrm{ng} / \mathrm{ml})$ for various times. At the times indicated, cell surface binding of ${ }^{125}$-IL-1 $\alpha$ (1 nM) was determined as described in "Materials and Methods." Nonspecific binding, assessed by the addition of 100-fold excess unlabeled ligand, has been subtracted from the data. Each point represents the mean of triplicate wells; variability of less than $5 \%$. 
a

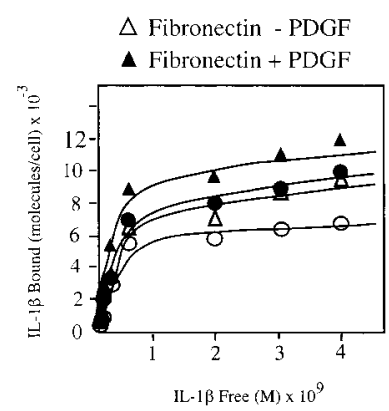

b

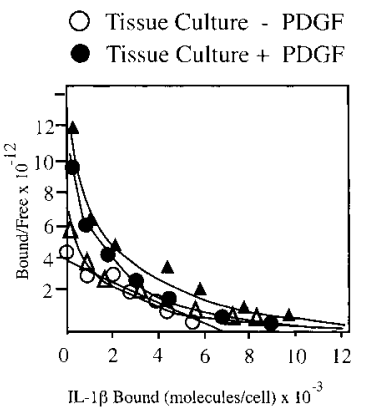

Figure 3.

Fibronectin attachment and PDGF-induced enhancement of IL-1 receptor levels involve induction of a second low-affinity IL-1 binding site. a, Smooth muscle cells were plated in the presence or absence of fibronectin and incubated for 12 hours with or without PDGF $(1 \mathrm{ng} / \mathrm{ml})$, followed by incubation with increasing concentrations of ${ }^{125} \mathrm{I}-\mathrm{IL}-1 \alpha$, as indicated. The level of specific IL-1 binding was determined as described previously. b, Scatchard analyses of data from cultures plated on fibronectin coated or uncoated tissue culture dishes and incubated with or without PDGF, as in a, as indicated. Data represent the mean of four experiments.

a

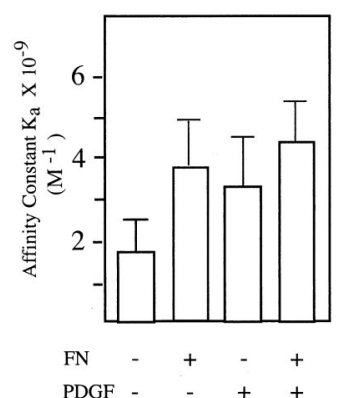

Figure 4.

PDGF and matrix attachment affect the binding characteristics of the type I IL-1 receptor and of the low-affinity site (the type III receptor). a, Cells plated on fibronectin or bare plastic were incubated with radiolabeled IL-1 $\alpha$ after 12 hours incubation with or without PDGF. Data were analyzed using MLAB as described in "Materials and Methods," and affinity constants $\left(K_{\mathrm{a}}\right)$ determined for the various conditions. Data represent the average of three experiments. $b$, Cells were plated and incubated with PDGF, and the binding activity (site number $\times$ affinity) of the low-affinity site, determined for conditions as in a, using MLAB. Data represent the mean of three experiments.

low-affinity binding site was more pronounced by attachment. Thus, fibronectin attachment caused an approximately 3 - to 4-fold increase in binding activity (site number $\times$ affinity), from $2.8 \pm 0.1 \times 10^{12} \mathrm{~mol} / \mathrm{cell}$ $\times \mathrm{M}^{-1}$ (TC) to $9.9 \pm 0.65 \times 10^{12} \mathrm{~mol} /$ cell $\times \mathrm{M}^{-1}(\mathrm{FN})$, whereas PDGF stimulation caused an approximately 2-fold enhancement (Fig. 4b). Combination of the two agonists had no additional effect on either binding site, suggesting overlapping mechanisms of induction or involvement of a limiting step in receptor regulation.

Confirmation that the low-affinity interaction constituted an independent binding site was demonstrated using a blocking monoclonal antibody, which completely inhibited IL-1 binding to the type I IL-1 receptor. These experiments showed an $80 \%$ reduction in specific cell surface binding, from $2.5 \times 10^{3}$ to $0.5 \times$ $10^{3}$ receptors/cell in cells on bare plastic. In contrast, only a partial reduction was observed in fibronectinattached cells. Thus, in these cultures approximately one-third of the binding was unaffected by addition of the blocking antibody. This corresponded to on average $50 \%$ of the matrix-induced response, demonstrating a significant amount of receptor type I-independent specific interaction (Fig. 5a). In addition, the increase in receptor binding induced by fibronectin attachment was blocked by soluble heparan sulfate (Fig. 5b), resulting in a reduction of approximately $50 \% \pm 12 \%$ of the total level of binding. Similarly, a pronounced reduction in binding of approximately $30 \%$ was observed in cells interacting with a mutant fibronectin lacking the heparin binding site (Fig. 5b), which coincided with an increase in average $\mathrm{K}_{\mathrm{a}}$ (not shown).

Further characterization of the second binding site was made by biochemical analysis after ${ }^{125} \mathrm{I}-\mathrm{IL}-1$ binding and chemical cross-linking. This demonstrated the induction of two bands containing the radiolabeled ligand in cells stimulated by PDGF or plated in the presence of fibronectin. Thus, in addition to an increase in a band of $97 \mathrm{kd}$, constituting the IL-1 receptor and the ligand, a higher molecular mass complex of 300 to $350 \mathrm{kd}$, was observed. Competition, using 100-fold excess cold ligand, resulted in complete inhibition of binding of radiolabeled IL-1 to the receptor type I as well as to the high molecular weight complex, demonstrating specificity of both interactions. Similar to our findings using fibroblasts (Valles et al, 1999), this contained up to $50 \%$ of the cross-linked IL-1 in cells attached to fibronectin (Fig. 6a). In comparison, the PDGF-induced high molecular weight complex observed in cells on bare plastic contained on average $25 \%$ of the specifically bound radiolabeled IL-1 (Fig. 6b), correlating with the less pronounced effect of the growth factor on binding activity of the low-affinity site (Fig. 5b). In contrast, PDGF had no effect on the level of the high molecular weight complex in cells on fibronectin (not shown). Similar to the IL-1 binding fibronectin-induced high molecular weight complex in fibroblasts, enzyme digestion demonstrated this second site to constitute a heparan sulfate with a core protein of approximately 90 kd (Fig. 6c). Further, gel electrophoresis, after immunoprecipitation using a nonblocking monoclonal antibody to the type I receptor, showed both IL-1containing bands, demonstrating a direct interaction between the heparan sulfate and the signaling IL-1 receptor within the high molecular weight complex (Fig. 6d).

\section{Discussion}

We report here that PDGF induction of IL-1 receptor levels is due in part to enhancement of an attachmentregulated IL-1 binding site, constituting a heparan sulfate. Further, the data show that in SMCs, this functions as a specific low-affinity binding site that interacts with ligand independently of IL-1 binding to the type I receptor. 
a

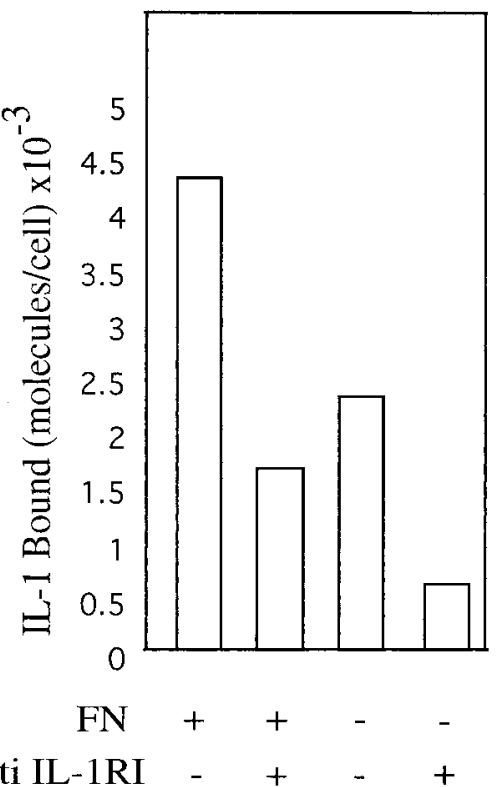

b

Figure 5.

The increase in cell surface binding is partially independent of binding to the type I IL-1 receptor and partially dependent on heparan sulphate binding. a, Cells plated on fibronectin or on bare plastic, as described previously, were incubated with radiolabeled IL- $1 \alpha$ in the presence or absence of a blocking anti-type I IL-1 receptor monoclonal antibody (anti-IL-1R1), as indicated, and the level of specific $\mathrm{IL}-1$ receptor binding was measured as in Figure 1. Data shown represent the mean of two experiments. b, Cells were plated on fibronectin in the presence or absence of soluble heparan sulfate, as described in "Materials and Methods" or on a mutant fibronectin lacking the heparan binding site (FN-Hep mut) and the level of receptors were assessed by using radiolabeled $\mathrm{IL}-1 \alpha$

Our data show that PDGF, as earlier reported (Bonin and Singh, 1988), and fibronectin attachment have a pronounced effect on IL-1R function in SMCs, involving an increase in type I receptor expression. The enhancement may to some extent reflect an increase in the rate of translocation of receptor protein to the cell surface. This alone is not likely to result in the effects observed, because approximately $95 \%$ of the newly synthesized protein is at any given time expressed at the cell surface (Slack et al, 2000; Urdal et al, 1988). The increase in cell surface binding by fibronectin attachment could, in addition, be due to retardation in the basal internalization rate, after stabilization in focal adhesions (Qwarnstrom et al, 1991). Receptor regulation as a direct consequence of matrix deposition could also in part explain the increase induced through PDGF stimulation (Ross, 1993, Wight, 1995). Further, trapping and immobilization of the IL-1 receptor complex at the cell surface is consistent with the demonstrated recruitment of the high molecular mass component.

Recruitment of the heparan sulfate is dependent on interaction with the heparin-binding site of fibronectin (Valles et al, 1999) and likely involves accumulation of the proteoglycan at focal adhesions after attachment. In addition, the increase in IL-1 binding to the high molecular weight complex could reflect a general enhancement in the level of the cell surface heparan sulfate, due to increased synthesis. This likely contributes significantly to the PDGF-induced response, because this growth factor has been shown to cause a pronounced increase in proteoglycan synthesis (Wight, 1995; Schonherr et al, 1997). An enhanced level of transport or translocation may also be involved in the attachment-induced increase. This is supported by the lack of additional effect by PDGF stimulation of cells on fibronectin, suggesting that at least in part, growth factor and structural regulation are induced through an overlapping mechanism.

5 The high molecular weight complex containing the heparan sulfate was implicated as constituting the low-affinity site, because in conditions where it was not induced, such as in the absence of either fibronectin binding or PDGF, Scatchard analysis showed a single site and resulted in an increase in average affinity. In addition, it was the only ligand binding species, other than the type I receptor demonstrated by cross-linking, and with a relative amount that corresponded to the amount of heparan sulfate-sensitive binding. With a $\mathrm{K}_{\mathrm{a}}$ in the range of $10^{5} \mathrm{M}$ (Valles et al,1999), the interaction is similar to that of integrin and matrix interaction and approximately 100-fold lower than that of the heparan-fibroblast growth factor interaction (Yayon et al, 1991). These low-affinity binding sites demonstrated in a number of systems such as nerve growth factor (Sutter et al, 1979), insulin (Corin and Donner, 1982), PDGF (Williams et al, 1984), and IL-2 (Robb et al, 1984), which, although generally nonfunctional, can be rapidly recruited into the highaffinity pool.

Our data suggest a dual role for the IL-1 receptorassociated cell-surface heparan sulfate in SMCs. On the one hand, effects on receptor function, such as changes in affinity, could result from the direct interaction with the type I receptor, demonstrated by immunoprecipitation. This type of effect, induced 
a

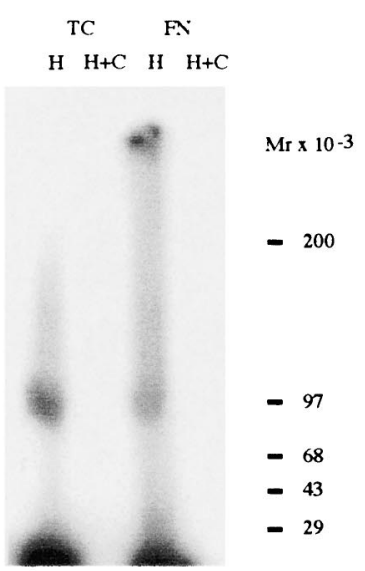

b TC

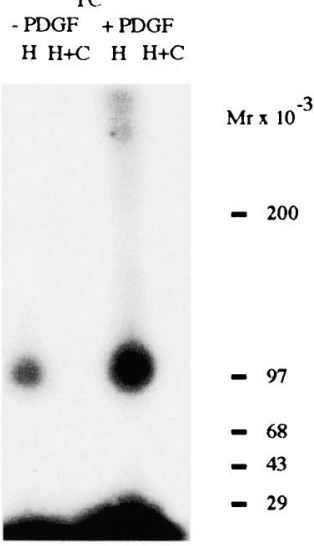

c

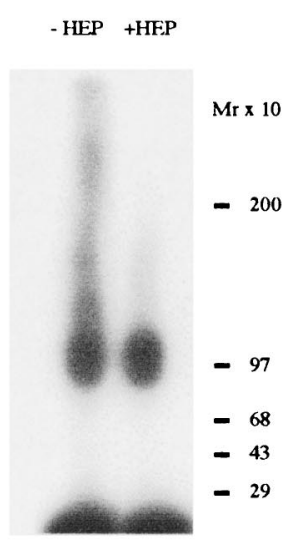

d

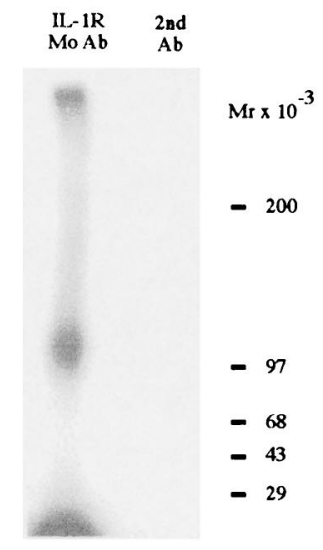

Figure 6.

PDGF-induced enhancement of IL-1 receptor levels involves induction of an attachment-regulated heparan sulfate. a, Cells were plated on bare plastic (TC) or on fibronectin (FM) and incubated with radiolabeled IL-1 $\alpha$, and IL-1-associated complexes visualized by SDS-PAGE, using gradient gels (4\% to $12 \%$ ) after cross-linking. $H$, radiolabeled IL-1 $\alpha(1 \mathrm{~nm}) ; H+C$, control lane with radiolabeled IL-1 $\alpha(1 \mathrm{~nm})+$ unlabeled IL-1 $\alpha(100 \mathrm{~nm})$; b, Cells were plated on bare tissue culture plastic and incubated with or without PDGF (1 ng/ml) for 12 hours and subsequently with ${ }^{125} \mathrm{I}-\mathrm{IL}-1$. IL-1-associated complexes were visualized by SDS-PAGE after cross-linking, and immunoprecipitation using an anti-IL-1 receptor monoclonal antibody. C, Characterization of the high molecular weight band in cells plated and stimulated as previously described was carried out using enzyme digestion after cross-linking. Cell extracts were incubated in the presence or absence of heparinase (HEP; 0.2 units $/ \mathrm{ml}$ ) for digestion of glycosaminoglycan chains, before separation by gel electrophoresis ( $3 \%$ to $12 \%$ SDS-PAGE). d, Interaction with the IL-1 receptor (IL-1R) was determined by immunoprecipitation after cross-linking. Cell extracts were immunoprecipitated with an anti-IL-1 receptor antibody and subsequently subjected to SDS-PAGE. The negative control shown $(2 n d A b)$ is immunoprecipitation carried out in the presence of the second antibody and beads alone.

through both nonligand-binding (Gearing et al, 1992; Kishimoto et al, 1995; Wight et al, 1992; Yamaguchi et al, 1990) and ligand-binding (Chieferz et al, 1988; DiGabrielle et al, 1998; Yayon et al, 1991) subunits has been shown to play an important role in regulation of cytokine and growth factor responses. The ability to bind ligand independently, in addition, could affect biologic responses through the type I receptor, by serving as a decoy, thus regulating effective ligand concentrations. Regarding effects through these two mechanisms, the heparan sulfate would act similarly to $\beta$-glycan, the nonsignaling type III TGF- $\beta$ receptor (Chieferz et al, 1988; Lopez-Casillas et al, 1993). Specific regulation of signaling by ligand binding subunits could similarly result from indirect effects, mediated through the main receptor, or could be induced directly after independent activation. We have recently demonstrated that induction of IL-1 activated genes through specific structurally regulated second messengers involve distinct signaling components of the type I receptor complex (Caunt et al, 2001). These data thus suggest that although the heparan sulfate functions as an independent unit (type III IL-1 receptor) within the $\mathrm{IL}-1$ receptor complex as regards ligand interactions, induction of downstream events are likely at least in part dependent on activation through the type I IL-1 receptor.

These results show that PDGF regulation of $\mathrm{IL}-1$ receptor levels involve enhancement of a low-affinity binding site constituting a heparan sulfate. The recruitment of this component to the IL-1 receptor complex correlates with structural augmentation of IL-1 signaling (Qwarnstrom et al, 1994; Zhu et al, 1998), as well as involvement of structurally regulated second messengers in IL-1-induced gene activation (Caunt et al,
2001). The data thus suggest that regulation of this receptor component constitutes a mechanism through which PDGF can enhance inflammatory responses, specifically in coregulation with structural events.

\section{Materials and Methods

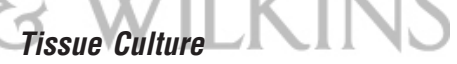

Monkey arterial SMCs (transfer 9-14) (kindly provided by Professor Russell Ross and Research Professor Elaine Raines, University of Washington, Seattle, Washington) were used. Cells were plated in 10-cm dishes $\left(3 \times 10^{6}\right.$ cells/dish) or 24 -well $\left(5 \times 10^{4}\right.$ cells/ well) tissue culture plates, on bare tissue culture plastic or in wells coated with fibronectin (FN, 10 $\mu \mathrm{g} / \mathrm{ml}$, GIBCO BRL, Gaithersburg, Maryland) (Brown and Juliano, 1985; Qwarnstrom et al, 1991, 1994). In some experiments, cells were incubated before plating and plated in the presence of heparin $\left(10^{-5} \mathrm{M}\right)$ (Valles et al, 1999). Cells were also plated on the same concentration $(10 \mu \mathrm{g} / \mathrm{ml})$ of a wild-type or mutant version of the $\mathrm{H} / 95$ recombinant fibronectin containing the Hepll/IIICS region (Makarem et al, 1994). The mutant protein was altered in the main heparinbinding region in Hepll (PPRRARVT to PPSSASVT) and in one site in the IIICS region (HGFRRTTP to PPSSASVT and IRHRPRPY to ISHSPSPY) as in Valles et al (1999). After detachment using EDTA (5 mm), as previously described (Ostberg et al, 1995), cells were allowed to attach for 3 to 4 hours in $10 \%$ FCS. In some experiments, cells were serum starved by incubation with $1 \%$ calf serum 3 to 5 days after plating, and subsequently stimulated with PDGF-AA (1 $\mathrm{ng} / \mathrm{ml})$ 
(kindly provided by Professor Russell Ross and Research Professor Elaine Raines) (Raines et al, 1989) for various time periods.

\section{Radiolabeling of Human IL-1}

Recombinant human IL- $1 \alpha$ (kindly provided by Dr. Steve Poole, National Institute for Biological Standards and Control) was radiolabeled with ${ }^{125}$ l by a modified chloramine-T method, as described previously (Dower et al, 1986; Qwarnstrom et al, 1988). Briefly, $30 \mathrm{ng}$ of IL- $1 \alpha(1.71 \mathrm{nmol})$ in $10 \mu \mathrm{l}$ of PBS was incubated with $5 \mathrm{mCi}(2.0 \mathrm{nmol})$ of sodium ${ }^{125}$ /-iodide (New England Nuclear, Boston, Massachusetts) in 25 $\mu \mathrm{l}$ of $0.5 \mathrm{M}$ sodium phosphate, $\mathrm{pH} 7$, and $30 \mu \mathrm{l}$ of 1.4 $\times 10^{-4} \mathrm{M}$ chloramine-T $(4.2 \mathrm{nmol})$ for 30 minutes on ice. The reaction mixture was fractionated and the reaction terminated by rapid filtration on a 1-ml bed volume Biogel P6 column (BioRad, Hertfordshire, England) preblocked with BSA (1\% w/v in PBS). After elution with PBS, fractions 2 to $4(100 \mu$ l each) containing the labeled protein were pooled. The labeled protein had a specific activity in the range 3 to 6 $\times 10^{15} \mathrm{dpm} / \mathrm{mmol}$.

\section{Binding Experiments}

Binding experiments were carried out as described previously (Dower et al, 1986; Qwarnstrom et al, 1988; Valles et al, 1999). Briefly, monolayer cultures plated on fibronectin-coated plates or on bare plastic, as described previously, were washed twice with fresh medium. Subsequently, binding medium (RPMI 1640, with $1 \%$ BSA, $20 \mathrm{~mm}$ HEPES, $\mathrm{pH} 7.2$, and $0.1 \%$ sodium azide; $1 \mathrm{ml} / 10^{5}$ cells) containing the appropriate concentration of ${ }^{125}-I_{-}-1 \alpha$, was added to the wells. Nonspecific binding was measured using 100fold excess unlabeled IL-1 for each concentration. Cultures were incubated at $4^{\circ} \mathrm{C}$ for 2 hours using a gyrorotary shaker to ensure continuous mixing of the supernatant. The incubation time chosen was based on previous kinetic studies (Qwarnstrom et al, 1988). Association kinetics experiments were performed at two IL-1 concentrations (0.1 and $1 \mathrm{~nm}$ ). In some experiments the binding experiments were carried out in binding medium alone or in the presence of PDGF-AA (1 ng/ml) as mentioned previously, and/or in the presence of heparin $\left(10^{-5} \mathrm{M}\right)$ (Valles et al, 1999). The monolayers were washed rapidly with ice-cold binding medium to remove unbound ligand, and harvested after incubation at $37^{\circ} \mathrm{C}$ for 15 minutes in trypsin/EDTA (0.05\%/0.02\%). Bound ${ }^{125} \mathrm{I}-\mathrm{IL}-1$ was measured in a beta-counter. Nonspecific binding data were analyzed by curve-fitting as previously described (Valles et al, 1999). In addition, specific binding was measured in the presence of a blocking anti-IL-1RI monoclonal antibody (M4; $\left.10^{-7} \mathrm{M}\right)$ (Slack et al, 1993), which demonstrated significant binding and specificity for the monkey type I IL-1 receptor. Nonspecific binding measured in the presence of $10^{-7} \mathrm{M}$ unlabeled ligand and data analyzed by MLAB Mathematical Modeling System (Civilized Software, Inc., Silver
Spring, Maryland) as described (Qwarnstrom et al, 1988; Valles et al, 1999).

\section{Cross-Linking and Gel Electrophoresis}

Cells were incubated with radiolabeled ligand and rinsed, as described previously. Before harvesting, cultures were incubated with the amine-directed cross-linking agent $\mathrm{BS}^{3}(0.1 \mathrm{mg} / \mathrm{ml}$; Pierce, Cheshire, England) (Park et al, 1987). After harvesting by EDTA $(5 \mathrm{~mm})$ and centrifugation $\left(1,000 \mathrm{rpm}, 5\right.$ minutes, $\left.4^{\circ} \mathrm{C}\right)$ the cell pellet was resuspended in extraction buffer (1\% Triton X-100, 2 mm PMSF, $1 \mu \mathrm{m}$ pepstatin, $1 \mu \mathrm{M}$ leupeptin; $50 \mu \mathrm{l} / 10^{6}$ cells) and incubated 15 minutes on ice. After centrifugation (10,000 rpm, 5 minutes) supernatant from samples was mixed with an equal volume of $2 x$ sample buffer $(0.1 \mathrm{~m}$ Tris- $\mathrm{HCl}, \mathrm{pH} 6.8$, $1 \%$ SDS, $10 \%$ glycerol, $0.0025 \%$ bromophenol blue and $0.25 \%$ 2-mercapto-ethanol), and boiled for 5 minutes. Extracts were separated by SDS-PAGE (3\% to $12 \%$ or $4 \%$ to $12 \%$ ), using the stacking gel procedure of Laemmli (1970). Dried gels were allowed to expose film (Kodak, X-Omat) with intensifying screens (Hypercassette; Amersham, Buckinghamshire, England) for 3 to 7 days at $-70^{\circ} \mathrm{C}$. For quantification, autoradiograms were scanned with a ScanJet Ilcx, (Hewlett Packard, Boise, Idaho) connected to a power Macintosh and analyzed using $\mathrm{NIH}$ Image (provided by Mr. Wayne Rasband, U.S. NIH).

\section{Heparinase Digestion}

After cross-linking, samples were digested with heparinase $\left(0.2\right.$ units $/ \mathrm{ml}, 6$ hours at $\left.37^{\circ} \mathrm{C}\right)(E C 4.2 .2 .7)$ (Sigma, Dorset, England) in a Tris- $\mathrm{HCl}$ buffer $(50 \mathrm{~mm}$, $\mathrm{pH}$ 7.0) containing $10 \mathrm{~mm} \mathrm{CaCl}_{2}$ (Carey and Stahl, 1990) and in the presence of $0.01 \mathrm{~mm}$ leupeptin and $0.01 \mathrm{~mm}$ pepstatin, with equal amounts of fresh enzyme added at 3 hours. After digestion, samples were analyzed using gel electrophoresis, as described previously.

\section{Immunoprecipitation}

Cells plated on fibronectin were incubated with radiolabeled IL-1 $\alpha$ for 2 hours, rinsed, and incubated with cross-linking agent, harvested, and extracted, as described previously. After preclearing with secondary antibody (rabbit anti-rat, $290 \mu \mathrm{g} / \mathrm{ml}$ ) and protein A-agarose beads $(12.5 \mu \mathrm{l} / \mathrm{ml}$; Santa Cruz Biotechnology), samples $\left(20 \mu \mathrm{l} / 10^{6}\right.$ cells) were subjected to immunoprecipitation by adding a nonblocking antihuman type I IL-1 receptor rat monoclonal antibody (M8, $5 \mu \mathrm{g} / \mathrm{ml}, 1$ hour at $4^{\circ} \mathrm{C}$ ) (Slack et al, 1993) which demonstrated significant affinity and specificity for monkey type I IL-1 receptor. Subsequently, a secondary antibody (rabbit anti-rat; Dako, Carpinteria, California) $(1: 20,290 \mu \mathrm{g} / \mathrm{ml})$ and prewashed protein A-agarose beads $(12.5 \mu \mathrm{l} / \mathrm{ml}$, Santa Cruz Biotechnology) were added to each sample, followed by incubation for an additional 1 hour at $4^{\circ} \mathrm{C}$. Samples were spun in a microcentrifuge $(10,000 \mathrm{rpm}$ for 1 minute at $4^{\circ} \mathrm{C}$ ) and washed three times with RIPA buffer (150 
$\mathrm{mm} \mathrm{NaCl}_{2}, 50 \mathrm{~mm}$ Tris- $\mathrm{HCl}, \mathrm{pH} 7.5,0.5 \%$ deoxycholate, $0.5 \%$ Nonidet P-40, and $0.1 \%$ SDS) and once with HEPES (10 mm, pH 7.5). After the final wash, the pellet was resuspended in electrophoresis sample buffer (50 $\mu \mathrm{l} / 10^{6}$ cells) and analyzed by SDS-PAGE, as described previously.

\section{Acknowledgements}

IL-1 $\alpha$ was a generous gift from Dr. Steve Poole (NIBSC). PDGF-AA and the smooth muscle cells were generous gifts from Professor Russell Ross and Research Professor Elaine Raines (University of Washington, Seattle, Washington). The recombinant fibronectin fragments wild type and mutant were a gift from Professor Martin Humphries (University of Manchester).

\section{References}

Bonin PD and Singh JP (1988). Modulation of interleukin-1 receptor expression and interleukin-1 response by platelet derived growth-factor in fibroblasts. J Biol Chem 263:1105211055.

Bornfeldt KE, Raines EW, Graves LM, Skinner MP, Krebs EG, and Ross R (1995). Platelet derived growth factor: Distinct signal transduction pathways associated with migration versus proliferation. Ann NY Acad Sci 766:416-430.

Brand K, Page S, Rogler G, Bartsch A, Brandl R, Dnuechel R, Page M, Kaltschmidt C, Baeuerle PA, and Neumeier D (1996). Activated transcription factor nuclear factor-kappa Bis present in the atherosclerotic lesion. J Clin Invest 97:17151722.

Brown PJ and Juliano RL (1985). Selective inhibition of fibronectin-mediated cell adhesion by monoclonal antibodies to a cell-surface glycoprotein. Science 228:1448-1451.

Carey DJ and Stahl RC (1990). Identification of a lipidanchored heparan sulfate proteoglycan in Schwann cells. J Cell Biol 111:2053-2062.

Caunt J, Kiss-Toth E, Carlotti F, Chapman R, and Qwarn strom EE (2001). Ras controls tumor necrosis receptorassociated factor (TRAF) 6-dependent induction of nuclear factor-kB-selective regulation through receptor signalling components. J Biol Chem 276:6280-6288.

Chieferz S, Andres JL, and Massague J (1988). The transforming growth factor-beta receptor type III is a membrane proteoglycan: Domain structure of the receptor. J Biol Chem 263:16984-16991.

Corin RE and Donner DB (1982). Insulin receptors convert to a higher affinity state subsequent to hormone binding: $A$ two-state model for the insulin receptor. J Biol Chem 257: $104-110$.

DiGabrielle AD, Lax I, Chen I, Svahn CM, Jaes M, Schlessinger J, and Hendrickson WA (1998). Structure of a heparinlinked biologically active dimer of fibroblast growth factor. Nature 393:812-817.

Dower SK, Kronheim SR, Hopp TP, Cantrell M, Deeley M, Gillis S, Henney CS, and Urdal DL (1986). The cell surface receptors for interleukin-1 alpha and interleukin-1 beta are identical. Nature 324:266-268.
Dower SK, Qwarnstrom EE, Page RC, Blanton RA, Kupper TS, Raines E, Ross R, and Sims JE (1990). Biology of the interleukin-1 receptor. J Invest Dermatol 94(Suppl 6):68-73.

Gearing DP, Comeau MR, Friend DJ, Gimpel SD, Thut CJ, McGourty J, Brasher KK, King JA, Gillis S, Mosely B, Ziegler SF, and Cosman D (1992). The IL-6 signal transducer, gp w130: An oncostatin M receptor and affinity converter for the LIF receptor. Science 255:1434-1437.

Heldin CH and Westermark B (1990). Platelet-derived growth factor: Mechanism of action and possible in vivo function. Cell Regul 1:555-566.

Kishimoto T, Akira S, Nrazaki M, and Taga T (1995). Interleukin-6 family of cytokines and gp130. Blood 86:12431254.

Laemmli UK (1970). Cleavage of structural proteins during the assembly of the head of bacteriophage T4. Nature 277:680-685.

Lopez-Casillas F, Wrana JL, and Massague J (1993). Betaglycan presents ligand to the TGF beta signaling receptor. Cell 73:1435-1444.

Makarem R, Newham P, Askari JA, Green LJ, Clements J, Edwards M, Humphries MJ, and Mould AP (1994). Competitive binding of vascular cell adhesion molecule- 1 and the HeplI/IIICS domain of fibronectin to the integrin alpha 4 beta 1. J Biol Chem 269:4005-4011.

Ostberg CO, Zhu P, Wight TN, and Qwarnstrom EE (1995). Fibronectin attachment is permissive for IL-1 mediated gene regulation. FEBS Lett 367:93-97.

Park LS, Friend D, Sassenfeld HM, and Urdal DL (1987). Characterization of the human B cell stimulatory factor 1 receptor. J Exp Med 166:476-488.

Qwarnstrom EE, MacFarlane SA, Page RC, and Dower SK (1991). Interleukin 1 beta induce a rapid phosphorylation and redistribution of talin: A possible mechanism for modulation of fibroblast focal adhesion. Proc Natl Acad Sci USA 88: 1232-1236.

Qwarnstrom EE, Ostberg CO, Turk LG, Richardson CA, and Bomsztyk K (1994). Fibronectin attachment activates the NF-Kappa B p50/p65 heterodimer in fibroblasts and smooth muscle cells. J Biol Chem 269:30765-30768.

Qwarnstrom EE, Page RC, Gillis S, and Dower SK (1988). Binding, internalization, and intracellular localization of interleukin- 1 beta in human diploid fibroblasts. J Biol Chem 263:8261-8269.

Raines EW, Dower SK, and Ross R (1989). Interleukin-1 mitogenic activity for fibroblasts and smooth muscle cells in due to PDGF-AA. Science 243:393-396.

Raines EW and Ross R (1993). Smooth muscle cells and the pathogenesis of the lesions of atherosclerosis. Br Heart $\mathrm{J}$ 69(Suppl):30-37.

Robb RJ, Greene WC, and Rusk CM (1984). Low and high affinity cellular receptors for interleukin 2 . Implications for the level of Tac antigen. J Exp Med 160:1126-1138.

Ross R (1993). The pathogenesis of atheroscerosis: A perspective for the 1990's. Nature 362: 801-809.

Schonherr E, Kinsella MG, and Wight TN (1997). Genistein selectively inhibit platelet-derived growth factor-stimulated versican biosynthesis in monkey arterial smooth muscle cells. Arch Biochem Biophys 339:353-361. 
Slack J, McMahan Waugh S, Schooley K, Spriggs MK, Sims JE, and Dower SK (1993). Independent binding of interleukin-1 alpha and interleukin-1 beta to type I and type II interleukin-1 receptors. J Biol Chem 268:2513-2524.

Slack J, Schooley K, Bonnert TP, Mitcham JL, Qwarnstrom EE, Sims JE, and Dower SK (2000). Identification of two major sites in the Type I interleukin-1 receptor cytoplasmic region responsible for coupling to pro-inflammatory signaling pathways. J Biol Chem 275:4670-4678.

Sutter A, Riopelle RJ, Harris-Walker RM, and Schooter EM (1979). Nerve growth factor receptors: Characterization of two distinct classes of binding sites on chick embryo sensory ganglia cells. J Biol Chem 254:5972-5982.

Urdal DL, Call SM, Jackson JL, and Dower SK (1988). Affinity purification and chemical analysis of the interleukin-1 receptor. J Biol Chem 263:2870-2877.

Valles S, Tsoi C, Huang WY, Wyllie D, Carlotti F, Askari JA, Humphries MJ, Dower SK, and Qwarnstrom EE (1999). Recruitment of a heparan sulfate subunit to the interleukin-1 receptor complex: Regulation by fibronectin attachment. J Biol Chem 274:20103-20109.
Wight TN (1995). The extracellular matrix and atherosclerosis. Curr Opin Lipidol 6:326-334.

Wight TN, Kinsella MG, and Qwarnstrom EE (1992). The role of proteoglycans in cell adhesion, migration and proliferation. Curr Opin Cell Biol 4:793-801.

Williams LT, Tremble PM, Lavin MF, and Sunday ME (1984). Platelet-derived growth factor receptors form a high affinity state in membrane preparations: Kinetics and affinity crosslinging studies. J Biol Chem 259:5287-5294.

Yamaguchi Yu, Mann D, and Ruoslahti E (1990). Negative regulation of transforming growth factor-beta by the proteoglycan decorin. Nature 346:281-284.

Yayon A, Klagburn M, Esko JD, Leder P, and Ornitz DM (1991). Cell surface, heparin-like molecules are required for binding of basic fibroblast growth factor to its high affinity receptor. Cell 64:841-848.

Zhu P, Xiong W, Rodgers G, and Qwarnstrom EE (1998). Regulation of interleukin-1 signalling through integrin binding and actin reorganization: Disparate effects on NF- $\kappa \mathrm{B}$ and stress kinase pathways. Biochem J 330:975-981.

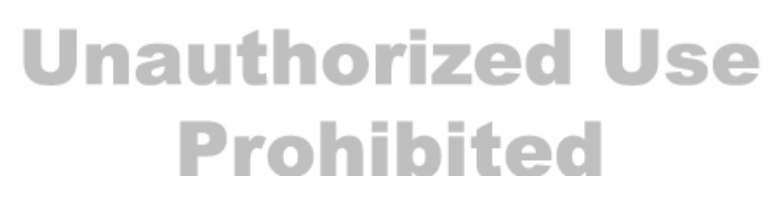

